\title{
Health risks, governance and changes in ecotourism paradigms during Covid19 pandemic, case study of Essaouira Province in Morocco
}

\author{
Mohamed Boukherouk $^{1, *}$, Sidi Imad Cherkaoui ${ }^{2}$, and Adil El Filali ${ }^{1}$ \\ ${ }^{1}$ Laboratoire de Recherches des Sciences Appliquées à l'Environnement et au développement Durable \\ (SAEDD, Higher School of Technology of Essaouira, Cadi Ayyad University (Marrakech). \\ ${ }^{2}$ Ecole Supérieure de Technologie de Kénitra, Ibn Tofail University, B.P. 242, 14000, Kenitra, \\ Morocco.
}

\begin{abstract}
Tourism merits on natural spaces are not exhausted, namely economic dynamics, development of the local population's life conditions, species conservation and awareness of environmental protection. However, the damage caused by Coronavirus to natural and rural spaces has impacted such merits negatively, for example, suspension of tourism and recreation activities. Further, the rebirth of ecotourism will be slower and necessitates profound changes in travel design and service delivery. Hence, sustainability, sanitary and regulatory measures will probably help manage ecotourism systems. Nevertheless, these will be affected by the increase in exploring relations between nature and wildlife regarding zoonotic and vector-borne infections and the fragility of biodiversity. Because of his mobility, a tourist appears to be a potential pathogen transmission factor of infections to natural areas, local communities, ecotourism destinations, his country and the crossed ones. New procedures would reduce travel and control traveler's behavior, and interactions between travelers and wild animals. The slowdown in demand may thus hinder the development of ecotourism. Sensitivity to epidemiological risk and vector-borne diseases will be greater and the need for health-friendly tourism will be further strengthened.
\end{abstract}

\footnotetext{
* Corresponding author: $\underline{\text { m.boukherouk@uca.ma }}$
} 


\section{Introduction}

Covid19 rise is a moment of rupture [1,2] in ecotourism as in the various sectors and aspects of human life. In addition to the global pandemic risk, more than a year of stoppage of the activity has profoundly affected the tourism system $[3,4]$ and transformed the way in which tourism products are consumed, and more particularly those based on interactions with nature. The latter turn out to be the most affected since they call into question the relationship between human and nature $[5,6,7]$. The bitter reality of the birth of the Coronavirus outbreak in bat and/or pangolin populations puts us face to face with the permanent risk of zoonosis and pushes the international community to rethink its relationship to nature, and particularly in ecotourism

In Morocco, ecotourism products were developed steadily from the 1990s. It took the form of hiking activities in the mountains, pre-Saharan areas and the hinterland of traditional tourist poles first (Marrakech, Agadir, and Fes). Then, it spread gradually in other niches developed in more fragile ecosystems such as natural parks and sites of biological and ecological interest. The economic benefits of this activity had limited the rural exodus, diversified the activity of the local population and helped in nature and ecosystems protection and conservations. This is the case of Essaouira. Listed as a Human heritage by UNESCO since 2001, the city has an Archipelago classified as a "RAMSAR" wetland and "Site of Biological and Ecological Interest: SIBE."This last is retained in 1996 within the framework of the Master Plan for the Protected Areas of Morocco, taking into account its rich flora, marine and terrestrial fauna [8]. The area benefits from a great interest in preservation thanks to several assets: coastal and island dune system, vast Argan and cedar forest, protected fauna (Eleonore Falcon) in addition to species, especially in transit since the city is located on the migration routes of birds (Passerines, waders, raptors...) $[9,10]$. In addition, there are many authentic villages where local life is based on traditional subsistence farming in small plots and breeding of goats and camels in the Argan woodland biosphere reserve [11].

Paralyzed by the Coronavirus pandemic, the ecotourism in Essaouira has been suffering for more than a year now from the absence of tourists and the cessation of activity. Certainly, the coronavirus acts as an element of rupture of the impetus that ecotourism has taken in the territory. The closure of borders, bans on movement within the country and the imposition of travel permits have dampened the desire for travel. Consequently, the actors plunged into a negative spiral and the ecosystems suffered from the cessation of money transfers for the preservation and conservation of species and environments.

If return to normal would seem difficult, given the current economic situation, the beginnings of the recovery will have to be done under the sign of the biosecurity risk for populations and species. Ecotourism should more than ever before take into account health considerations to meet the needs of Eco tourists without endangering the population and the environment. A health friendly approach to tourism is considered a crucial choice for which stakeholders are increasingly committed. The governance of the recovery is important to prepare for the post-covid.

This paper analyzes the new paradigms of ecotourism under the effect of rising health risks and biosecurity considerations. Through the case of the province of Essaouira, it highlights the multiple negative impacts on ecotourism, the ecotourism actors in the province and the governance model proposed for the revival. The results of a field survey make it possible to see how the new measures are applied and how the actors perceive them. It concludes to the difficulty of recovery in an ecotourism environment still under profound transformation and which will need to adapt to the biosecurity and health risk. 


\section{Methodology}

This paper uses a global and systemic vision, combining the deductive and inductive approaches. It tries, through a methodology borrowed from sociology and geography, to suggest a framework of the reality of a tourist destination during the period of Covid19; namely from the beginning of the lockdown until the opening of the Moroccan borders. A review of literature of the concepts of ecotourism, the interplay between human and nature and biological risks were necessary. Then, a documentary study, especially of the grey literature, with an analysis of the data of the official organizations and publications of the Moroccan and international tourist institutions allowed to understand the situation of the territory in relation to the national and international contexts.

The empirical part is made of an analysis of the protocols and guidelines proposed by the Moroccan authorities and which operate a change in ecotourism. In addition a qualitative study on a sample of 30 ecotourism professionals from the province was conducted. This study aimed to assess the impact of the crisis and the perception of the actors of the opening period, after lockdown, as well as the post-Covid period. The questionnaire was drawn up in French and Arabic. The first part of the questionnaire collected data on gender, age, level of education. The second part focused on the Covid19 impact on travel and ecotourism in the studied area, the undertaken actions, and the changes in ecotourism system under the influence of the pandemic and the operator's perception of these changes.

\section{Literature review}

The economic, social and ecological merits of ecotourism are legion both for territories $[12,13,14]$ and natural environments $[15,16]$. Based on the principles of sustainable development, it allows both the enhancement and the promotion of environments while aiming at the protection of the environment and its safeguard for future generations [17, $18]$.

The ecotourism orientation in Morocco was born from the commitment of the country, and the actors in the path of sustainable development, as it's the case in other developing countries [19]. The 2010 Vision, through the strategy of sustainable tourism boosted ecotourism in the country. Perceived, mainly as an opportunity for territories and fragile or marginal areas [20 21, and 22] literature has also developed extolling these different merits [23, and 24]. Moroccan researchers will tackle also the models, actors and sometimes criticize the risks of gentrification [25] and excessive levels of overtourism.

Literature on ecotourism and tourism, in general, has not overlooked the problems that can arise from the interaction of human with natural spaces and fauna. Indeed, Hall [26, 27] insists on the fact that tourism can be a vector of transmission and propagation of diseases, following the same reasoning of other authors which he quoted in his chapter book: ecotourism and biosecurity. He also provides a relevant analysis of the risks and mechanisms and strategies to counteract the biosecurity risks that can be amplified by the tourist activity [28, 29, 30, 32]. Of course, the interaction of humans and natural environments expose humanity to a large number of zoonosis and pandemic risks [31] like SARS [31, 33], H1N1 influenza [34, 35] and Ebola [36]. The question arose sharply putting the bio-security risk at the center of issues related to ecotourism [27].

The impacts of covid19 on tourism are not the only subject to have caught the attention of researchers. Several studies focused on post-Covid19 and changes that will occur in the future. As a moment of rupture [37] states try to respond to covid19 effects in an authoritarian manner [38, 39] while other think about its resilience capacity [40, 41]. 
Certain affirm that we cannot have a return to normal [42] while others suggest sustainable strategies to ecotourism recovery [43, 44].

For decades, ecotourism has helped to conserve nature and protect endangered species. COVID-19 and the subsequent closure of ecotourism sites has had an indelible impact on wildlife and the communities that protect it $[45,46]$.

Because of the pandemic, the loss of ecotourism revenue has affected livelihoods and wildlife conservation efforts due to the reduction of internationals travels to Morocco [47].

\section{Importance of ecotourism in Moroccan and Essaouira}

For two decades, sustainable development has been able to awaken environmental awareness and participate in the reshaping of the tourist offer under the pressure of an increasingly accumulated demand for responsible travel towards the environment and the local communities $[48,49]$. While it is still difficult to measure the flows and the impact on the environment, there is no doubt that ecotourism is constantly growing.

In 2000, International ecotourism society [50] published a factsheet in which we can read "Ceballos-Lascuráin (1993) reports a WTO estimate that nature tourism generates 7\% of all international travel expenditure (Lindberg, 1997). The World Resources Institute (1990) found that while tourism overall has been growing at an annual rate of 4\%, nature travel is increasing at an annual rate between 10\% and 30\% (Reingold, 1993). Data which support this growth rate is found in Lew's (1997) survey of tour operators in the AsiaPacific region who have experienced annual growth rates of $10 \%$ to $25 \%$ in recent years (Lindberg, 1997). WTO (1998) stated that ecotourism and all nature-related forms of tourism account for approximately 20 percent of total international travel." Currently, ecotourism seems to be reaching considerable proportions. For Vig \& Deshmukh [51] the ecotourism market size was valued at $\$ 181.1$ billion in 2019 , and is expected to reach \$333.8 billion by 2027, registering a CAGR of $14.3 \%$ from 2021 to 2027.

In 2018 the Center for Responsible Travel [52] estimated between 55\% and $66 \%$ the average number of travelers willing to pay more for brands committed to sustainability, social and environmental initiatives between 2014 and 2015. According to a study carried out by Booking.com, $73 \%$ of international travelers intended to stay at least once in ecoresponsible accommodation in 2019. That is to say before the appearance of covid19. According to the same study, this figure has increased for the $4^{\text {th }}$ consecutive year, going from $62 \%$ in 2016 , to $65 \%$ in 2017 and to $68 \%$ in 2018 [53].

Moreover, a study by the same website carried out in 2018 reveals the importance of environmental sensitivity without the influence of the travel truce induced by the pandemic. The results show that among the 12 markets surveyed, the vast majority of travelers $(87 \%)$ say they want to travel while limiting their impact on the environment, and $39 \%$ of travelers say they actually succeed in limiting this impact [54].

In Morocco, it is obvious that the development of ecotourism is largely linked to the inauguration of the Central High Atlas (P.H.A.C.) project in 1983 resulting from FrancoMoroccan cooperation. Nevertheless, the Toubkal massif has known a tourist tradition that dates back to the colonial period during which the first climbs to the summit of Toubkal took place between 1880 and 1990 .

Since the 1920s, under the French protectorate, the Toubkal massif has experienced tourist and sporting dynamics, in particular with the construction of high-altitude refuges and the Oukeïmeden resort. The Middle Atlas will experience the same process after the opening of Michlifen ski station in 1951. The post-independence period experienced a regression, which was overcome from the 1970s [55]. Subsequently, attendance at Toubkal National Park has increased steadily. According to estimates from the Ministry of Tourism, the number of visitors to the park via Imlil village was around 10,000 people [56], so the 
latest statistics put forward in the official HCEFLCD website is 40000 tourists per year in 2004. The statistics on arrivals in rural areas remain interesting but are lacking. On the basis of the estimates of the experts who carried out the study on the Moroccan rural tourism strategy, the ecotourism potential of the country can be estimated to 4,030,566 in 2000 . The assumption is that each client arriving in tourist accommodation is potentially a consumer of rural tourism in nearby areas. This allowed them to estimate the number of tourists who passed through rural areas between 2,099,924 or 2,656,142 in 2000 [57]. This study remains pioneer and interesting for several reasons. Although the fact that it's based on estimations, it reveals the potential of natural spaces and therefore the wide possibilities for developing ecotourism in the Kingdom.

In Essaouira province, tourist activity appeared in the shadow of Marrakech. Mainly, day trip city, for tourists from Marrakech, it has gradually developed its own products trying to stand out from the ocher city and from Agadir in the south. Around a nucleus of its intramural city classified as a World Heritage Site by Unesco, the city of the trade winds is surrounded on its west side by an archipelago classified as a site of biological and ecological interest. Inside the country, an Argan grove classified as a biosphere reserve since 1995 populates the plains of the north and east and extends to the Western High Atlas in the south of the province. This endemic tree got its international day recently 2020 (May $\left.10^{\text {th }}\right)$ : the Argania Day. Also found in the region thuja forests and several species of endemic flora and fauna (Eleonora Falcon) and an authentic rural peasant life and ancestral know-how.

In the last two decades, the province of Essaouira has known a tourism dynamic. Thus, according to the local tourism office, the city has 231 accommodation units, mainly made up of small hotels, riads, guest houses and hostels ( $60 \%$ of the whole capacity) as well as 30 restaurants, 32 travel agencies and 34 guides. If the activity has been developed largely only in recent years, it is mainly thanks to the 2010 and 2020 visions which gave more importance to the province. The office estimates at 12,000 the number of direct jobs created in tourism and to 1.4 billion dirhams its incomes. The sector turnover is just over $22 \%$ of the province's GDP. The activity is gaining more and more importance both through employment and through its multiplier effect on all other sectors, in particular construction and trade [58].

The hinterland attracts tourists in search of adventure. Hikes with overnights in camps or homestays in the villages of Sidi Mbarek, Ain Lahjar or Idda Ou gourd are the major products. Surfing attracts wave's enthusiasts while ornithology is another niche to develop. Stays in farms and agritourism experiences are emerging, trying to attract tourists by developing a new offer for customers looking for new experiences. The city has only two hotels classified as Clef Verte (Green Key) [59]. Developed in France since 1998, La Clef Verte label is, by the number of labeled establishments and by its age, the first Eco label for sustainable accommodation in France. However, all tourist operators (guest houses, lodges and guides ...) and farmers try to promote and communicate with an ecological and organic orientation. This spirit is also the commitment of the local authority which has made the development of tourism in the hinterland a tool to position strongly and sustainably, their destination. Indeed, the Eco-nature program of the province tourist office in partnership with the provincial tourism council CPT is an example of an integrated development plan of Rural Tourism and Nature that was developed with different stakeholders. It aims the development of the ecotourism potential of this area. Unfortunately, that impetus was stopped by the pandemic. 


\section{Impact of coronavirus on ecotourism in Essaouira}

The covid19 pandemic has paralyzed the tourism sector. The decisions that states took to stop the spread of the pandemic have given a heavy blow to the dynamics in tourist areas, especially those relying on ecotourism. Indeed, without mobility all tourist activity has evaporated and with it jobs and revenues. The world tourism organization estimated the drop in the number of international tourists at $97 \%$ compared to 2019 during the period March to May 2020 (i.e. the period of drastic lockdown) [60]. This translates into a fall of 300 million tourist's arrivals and $\$ 320$ billion of incomes [60]. The effects of this crisis will certainly last until 2024 [61].

In Morocco, economic losses have been estimated at 1 billion dirhams per day of lockdown or one point of GDP every 10 days or the equivalent of 2,000 to 2,500 jobs lost per day. The tourism sector was also a quarantined sector because of the closure of sea and land borders, the suspension of flights, the closures of places of entertainment, etc.). Consequently, professionals were forced to suspend all their activities since mid-March. They quickly found themselves facing cash flow deficit, unable to honor their commitments even those of the short term (salaries, bank and insurance payments, etc.). The National Tourism Confederation (CNT) estimates the impact of the coronavirus in Morocco to $\$ 3.4$ billion by the end of the year and $70 \%$ the reduction for arrivals and more than $60 \%$ of overnights at the end of July 2020 [62].

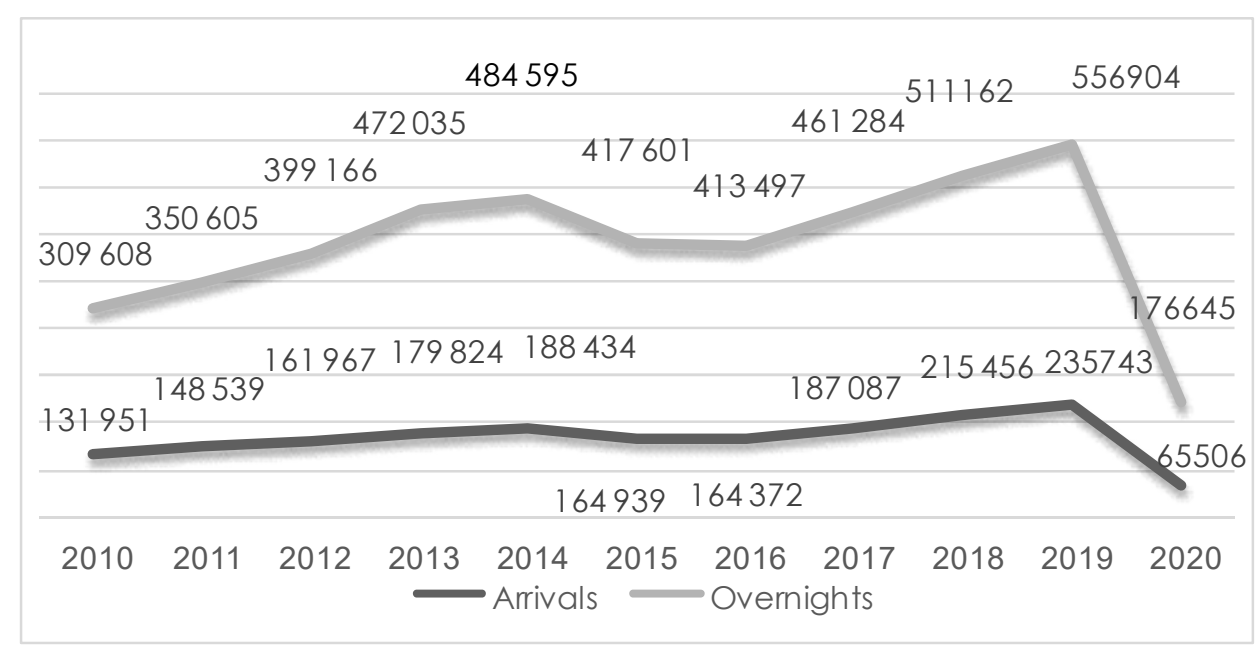

Fig. 1. Arrivals and overnights evolution in Essaouira province (2010-2020).

Locally, and in relation to the province subject of our study, Essaouira seems like a ghost town. Tourism covid19 crisis has impacted all aspects of life and all the tourism system. Hotels, restaurants, transporters, souvenir sellers (bazaars) have been closed since March 2020... Even more serious, our permanent observations confirms the negative multiplier effect on several other activities: agriculture, local commerce and real-estate sector... In other words and according to the province tourism office data: tourist arrivals cut down by $72 \%$, resulting in a $68 \%$ drop in overnights compared to the previous year (fig.1). Moreover, 51 accommodations (table.1) located outside the Medina of Essaouira are still closed temporarily, and a capacity of 1653 rooms continues to be closed today. They thus estimated the size of jobs lost at 170 direct jobs, just in the hinterland of Essaouira. The only official guide no longer works since March 2020 and neither do the twenty fake guides when all the Argan oil and Thuja cooperatives are still closed. 
Since no museums or Eco Museums exists in the province and no entry fee is imposed for tourists entering the reserve, the only data we have to estimate the volume of ecotourism is the hiking activity involving overnight in camps. It gives us an idea about the losses of ecotourism activity. Thus, after a gradual growth in the number of bivouacs since 2016, this activity has totally stopped because of the pandemic. (Fig.2)

Table. 1. Aaccommodation units closed due to the pandemic.

\begin{tabular}{|l|c|}
\hline \multicolumn{1}{|c|}{ Accommodation type } & Effective \\
\hline Hostels & 1 \\
\hline campings & 3 \\
\hline Lodges & 10 \\
\hline hotels & 6 \\
\hline Guest house & 30 \\
\hline Appart hotel & 1 \\
\hline Total & 51 \\
\hline
\end{tabular}

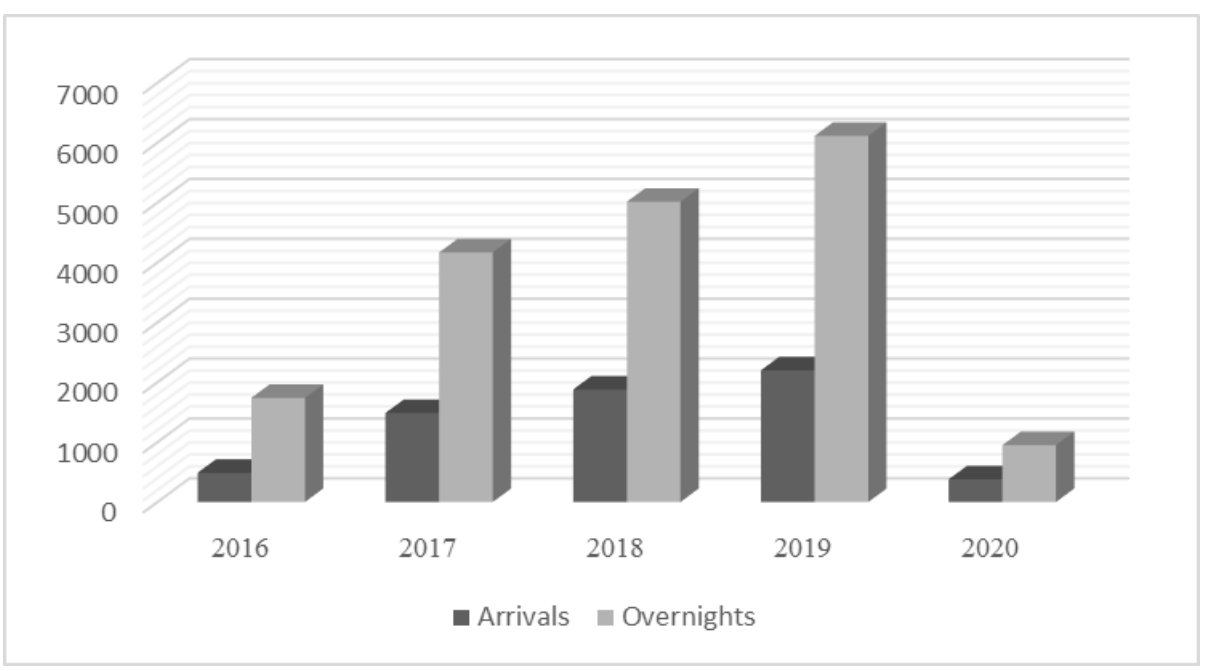

Fig.2. Evolution of camps arrivals and overnights (2016-2020)

\section{Environmental Governance of the crisis and ecotourism}

Ecotourism in Morocco brings together several actors and communities. However, no specific legal framework manages the development of nature activities. Only National Responsible Tourism Charter of 2006 serves as a basic frame of reference but lacks depth and clarity. The framework law ${ }^{\circ}$ 99-12 [63] on the National Charter for the Environment and Sustainable Development, promulgated in 2014 (Dahir, 2014), The Law of July 16, 2010, on protected areas, the law on environmental protection 2003 and the one on environmental impact studies (Law $n^{\circ} 12-03$ ) [64] provide a more precise framework and general measures but not specifically linked to tourist activities. In these texts, the relationship between human and nature must be respectful. It insists on environment safeguard and its sustainable management and urges the actors to embark on this path. None of the texts mentions the case of health crises and zoonosis.

Nevertheless, the monitoring and control system are rich with legal texts and organizations that participate in the surveillance and prevention of diseases. The modern health control legislation system dates back to 1916. It saw the reorganization of the maritime health police [65] and the organization of health control at land, sea and air 
borders [66]. They had as main mission the diseases watch (Cholera, plague and yellow fever) and the borders sanitary control in the ports, ports of call and all ships which should dock in the Moroccan ports. They had the power and ability to prohibit the boarding of persons and objects liable to spread transmissible diseases and take precautionary measures against the spread of these diseases (article 15, Dahir 1916) [65]. Since then, the system has been enriched by several texts and institutions.

The governance of the pandemic crisis is essentially dominated by the influence of national health authorities. There are thus central administration institutions such as the Department of Epidemiology and the Fight Against Diseases which provide epidemiological surveillance [67], The National Institute of Hygiene (INH), The National Virology Laboratory (INV) which deals with the surveillance, isolation and identification of viruses (polio, influenza in particular). These institutions are supported by external services, such as the Tuberculosis and Lung Disease Diagnostic Center (CDTMR) and the Environmental Epidemiology and Hygiene Laboratory (LEHM). At the local level there are the services of the Wilayas and its environmental health services: responsible of the supervision and control of actions related to the monitoring of environmental hygiene. Morocco's recent history of health crisis management has a long and rich experience. Several programs were put in place since mid-2000s. It's the case with zoonosis such as rabies and hydatid/echinococcosis and also those of Environmental hygiene programs (inspection of food industries, food control and restaurants). Fall into this category epidemiological surveillance of animal diseases (avian influenza, foot-and-mouth disease, African horse sickness, bovine spongiform encephalopathy,), and diseases such as blue tongue, sheep pox, tuberculosis, brucellosis, rabies...

The country has a National Animal Disease Epidemiological Surveillance Network (RENESMA) and an epidemiological surveillance program where several institutions collaborate with the Epidemiological Surveillance Service within the Department of Epidemiology and Disease Control. The program aims to regularly collect and analyze surveillance data to feed the alert system to detect early epidemic phenomena and prepare for the response. This program has a history of the epidemiological situation of notifiable diseases, made as early as 1980 . The Epidemiological Surveillance Service also manages global alerts and disasters. This was the case of SARS-Cov in 2003 [68]. Indeed, a special attention is paid to influenza surveillance. In fact, avian influenza was at the origin of the creation of the service with a database fed by a network of sentinel centers in different parts of the Kingdom. In the same spirit, the service has a system dedicated to rotavirus gastroenteritis since 2006. Epidemiological surveillance in the Moroccan health system is carried out in partnership with the regional office for the Eastern Mediterranean of the WHO.

The governance of the period of the Covid19 pandemic was managed very early [69, 70]. After the declaration of the state of emergency, a set of institutions were involved in the management of the crisis for which a technical and scientific committee was created and which pilots and coordinates the decisions taken in the matter, in particular with regard to the restrictive and/or easing measures. Thus, coordination between different sectors is ensured by the Interministerial Crisis Management Committee (CIGC). The operation is coordinated by the Central Coordination Post (PCC) [70].

At another level, the Ministry of Health with its organs is strongly represented with its Steering Committee of the response of the health system where we find the Minister or the Secretary General of the Ministry of Health or who represents them. Various departments are also in this committee such as: the Department of Epidemiology and Disease Control (DELM); the Department of Hospitals and Outpatient Care (DHSA); the Directorate of Medicines and Pharmacy (DMP) [67]... In addition, the National Public Health Emergency Operations Center (CNOUSP), at the DELM level, monitors the epidemiological situation 
at the international level and coordinates the technical aspects of preparation and response. It also monitors the epidemiological situation of the disease at the national level and informs the various stakeholders and partners, the media and public opinion (according to Ministerial Decision No. 013065 of September 16, 2019, on the creation of CNOUSP, CROUSPs). [67].

At the regional level the crisis is managed by the Regional Centers for Public Health Emergency Operations (CROUSPs). It is set up at the level of the Regional Health Directorates (DRS), and is under the responsibility of the Head of the public health service. Its role is to monitor the epidemiological situation at the regional level and coordinate the technical aspects of preparation and response. It is supported in its mission by the regional intervention teams. The Chief and executives of the Public Health Service, the Director of the Regional Hospital Center (CHR) and a clinical doctor, preferably an infectious disease specialist, participate in this crisis ecosystem; the Biologist in charge of the CHR laboratory; the head of environmental health; the head of the Communication Unit; and Any other resource person whose presence is deemed useful [67, 68].. In addition to their mission of monitoring the epidemiological situation and steering the response within their region, the CROUSPs must play a leading role in the organization of training and awareness sessions for health professionals and the various stakeholders in the public and private health care structures. [68].

As far as the tourism sector is concerned, the state of emergency involved the prioritization of health and pandemic issues. The tourist authorities were unfortunately not consulted and remained awaiting announcements from the official authorities in charge of the crisis. The continuous extension of the state of health emergency since March 2020, the ban on travel at the national level and the accompanying health measures (for hotels, restaurants, travel agencies and the other sector companies) have been managed by the Ministry of interior and its regional and provincial bodies, notably the Wali and the governor. But tourism operators have not stopped asking for simplified procedures, at least for domestic tourism. They have repeatedly expressed their fears about the dislocation of the Moroccan tourism system because of the activity shutdown.

At the economic level, the governance of the crisis was based on the creation of an economic watch committee (CVE), at the level of the Ministry of the Economy, Finance and Reform of the Administration. This committee, which includes the economic departments alongside the Wali of the central bank of the Kingdom (Banque Al Maghrib) as well as the ministries of health and labor is responsible for monitoring the development of the economic situation and taking the appropriate measures to support the affected sectors. Since its first meeting on March 16, 2020, the committee has taken a number of measures to cushion the economic shocks due to the pandemic: suspension of the payment of social charges (CNSS contribution), the postponement of incomes declarations and corporation taxes payment, deferral of loan maturities, a loan guarantee and exceptional overdrafts (Damane Oxygène \& Auto-entrepreneur Guarantee) for companies affected by the crisis [71, 72]. Other measures aimed either at reducing the burden of debts and receivables or at proposing guaranteed financing mechanisms. The tourism operators benefited from the same measures, in addition to a Covid-19 lump sum, in compensation for lost wages. This allowance was set in the beginning of the crisis and has been extended several times until August 2021.

According to the interviewed operators, the governance of tourism paralysis, has been made under the waiting sign and the domination of measures taken from above. The restrictions lifting during the second part of 2020 was accompanied by new obligations. From now on operators should comply with measures of physical distance, impose barrier gestures, reduce passengers and clients in the same space or transportation and disinfect equipment's and premises permanently (table.2) [72]. The primacy of the management of 
the pandemic crisis and the risk of propagation become an obligation. To enforce its new measures, regular checks were carried out and led to companies' closure for those which not comply with the established instructions [73].

Table. 2. Summary of changes in tourism services due to covid19 period

\begin{tabular}{|c|c|}
\hline \multicolumn{2}{|c|}{$\begin{array}{l}\text { General measures: } \\
\text { Set up a special COVID } 19 \text { HR unit to control staff temperatures, report suspected cases, daily } \\
\text { brief the staff: } \\
\text { Set up shifts with a fixed staff. } \\
\text { Reinforced health and safety instructions. } \\
\text { Limit the number of customers present at hotel at the same time. } \\
\text { Mandatory and systematic update of all COVID } 19 \text { protection procedures. } \\
\text { Provide protective equipment: masks, face shields visors, disinfected uniforms. } \\
\text { Provide masks for customers and staff; (Compulsory - (to be renewed every } 4 \text { hours)) } \\
\text { Set up a quarantine procedure in case of a positive case among clients or staff; } \\
\text { Notify customers about the possibility of rehousing if required. } \\
\text { Compliance with social distancing measures in common areas. }\end{array}$} \\
\hline $\begin{array}{l}\text { Hotel } \\
\text { Booking, } \\
\text { Check-in } \\
\text { and Check- } \\
\text { out }\end{array}$ & $\begin{array}{l}\text { Priority remote reservations (online or phone). } \\
\text { Online check-in and payment, } \\
\text { Defer check-ins and check-outs to avoid the risk of overcrowding. } \\
\text { Avoid printing (prefer emails to be sent directly to the customer). } \\
\text { Set-up a crawl space of } 6 \text { hours between reservations. } \\
\text { Disinfection of luggage and keys (during the check-in and check-out). }\end{array}$ \\
\hline $\begin{array}{l}\text { Hotel Front } \\
\text { desk }\end{array}$ & $\begin{array}{l}\text { Comply with health and distancing measures in terms of capacity (50\%). } \\
\text { Ground marking to avoid reception hall overcrowding } \\
\text { Equip the reception desks with protective Plexiglas screens and separations. } \\
\text { Equip reception with a medical kit suitable: sanitizers, disinfectant wipes for } \\
\text { surfaces cleaning, gloves, and disinfectant spray. } \\
\text { Display of safety measures (screens or use posters in the reception hall). } \\
\text { Regular disinfection (front desk area, desks, lifts and common sanitary blocks). }\end{array}$ \\
\hline $\begin{array}{l}\text { Hotel } \\
\text { common } \\
\text { areas, } \\
\text { conference } \\
\text { centers, } \\
\text { pools and } \\
\text { beach }\end{array}$ & $\begin{array}{l}\text { Permanent display of the safety and hygiene measures for customers. } \\
\text { Redesign the kids clubs, limit reception capacity and hygiene measures. } \\
\text { Install sanitizer's dispensers. } \\
\text { Reinforced cleaning and disinfection guidelines. } \\
\text { Air filters cleaning and regular ventilation. Better use of natural ventilation. } \\
\text { Deactivate the electric hand dryers. } \\
\text { Disinfect vehicles. } \\
\text { Disinfection and cleaning of deckchairs and beach towels. } \\
\text { Sports halls, Hammam and Spa must comply with the guidelines; (Closed) } \\
\text { Possibility of keeping the seminar rooms open during the events; } \\
\text { The installation of parasols must respect social distancing measures. } \\
\text { Carry out a site zoning in the beaches. }\end{array}$ \\
\hline $\begin{array}{l}\text { Hotel rooms } \\
\& \text { floors }\end{array}$ & $\begin{array}{l}\text { Strict cleaning protocol for the rooms. } \\
\text { Train and inform staff on the Covid19 measures; } \\
\text { Limit the use of bathroom amenities to single use. } \\
\text { Use certified cleaning products for laundry. } \\
\text { Cleaning air filters and regular ventilation (Better use natural ventilation). }\end{array}$ \\
\hline $\begin{array}{l}\text { Restaurant } \\
\text { (Hotel and } \\
\text { outside } \\
\text { restaurants }\end{array}$ & $\begin{array}{l}\text { Train staff on good hygiene and safety practices against COVID } 19 . \\
\text { Put up awareness posters on prevention and protection measures against COVID } \\
19 . \\
\text { Regularly disinfect door handles, stair railings, chair armrests, tables, electronic } \\
\text { payment terminals and any other frequently touched work tool. } \\
\text { Disinfect equipment and accessories, made available to customers, before and after } \\
\text { use. } \\
\text { Temperature control for staff, clients and suppliers. } \\
\text { Respect of a minimum distance of } 1 \text { meter between } 2 \text { tables; }\end{array}$ \\
\hline
\end{tabular}




\begin{tabular}{|c|c|}
\hline & $\begin{array}{l}\text { Use separation screens } \\
\text { Servers must keep at least one meter from customers when ordering. } \\
\text { Suspend operations that require customers to use common utensils or vending } \\
\text { machines, such as salad bars, buffets and beverage vending machines. } \\
\text { Customer flow management for buffet and dedicated staff for every service; } \\
\text { Establish rules with suppliers to verify compliance with health security measures } \\
\text { related to COVID-19: delivery and reception staff for deliveries must be trained to } \\
\text { properly disinfect, unpack and clean products. } \\
\text { Adopted protocols in kitchen: handling of cutlery and utensils. } \\
\text { Encourage room service to avoid queues. } \\
\text { Room service should consider disposable packaging: boxes, cutlery... } \\
\text { Reinforce the cleaning of air filters, air conditioning and hoods. } \\
\text { At the entrance, access or high traffic areas (kitchen entrance, delivery area, etc.), } \\
\text { place a disinfectant non slipping mat and sanitizers dispensers. } \\
\text { Animation activities must respect social distancing measures. } \\
\text { Electronic payment. } \\
\text { Maximum } 4 \text { people per table with minimum distance respected (members of the } \\
\text { same family are excluded from this restriction). } \\
\text { Dedicate an area to take-away and home delivery service. } \\
\text { Practice social distancing during home delivery by opting for "contactless" } \\
\text { deliveries: send text messages or call when deliveries are ready. }\end{array}$ \\
\hline & $\begin{array}{l}\text { At the entrance access or heavy traffic areas, place a non-slipping disinfectant mat; } \\
\text { Regular disinfection of the premises. } \\
\text { Inform and educate staff and customers on hygiene and prevention rules. } \\
\text { Redesign offices to respect social distancing. } \\
\text { Limit and control the flow of customers: maximum of two customers } \\
\text { Mandatory floor marking outside the agency. } \\
\text { Encourage teleworking. } \\
\text { Develop online reservation channels. } \\
\text { Set up a hotline and social networks presence. } \\
\text { Guarantee transparency and inform customers of all the preventive and hygiene } \\
\text { measures required when preparing trips. } \\
\text { Distribute hygiene guidelines guides and safety practices on the agency's website } \\
\text { or on social networks. } \\
\text { Establish rules with suppliers and partners to verify compliance with health } \\
\text { security measures related to COVID-19. } \\
\text { Notify the possibility of rehousing when needed. }\end{array}$ \\
\hline Guides & $\begin{array}{l}\text { Comply with regulatory recommendation (within the framework of health crisis } \\
\text { management) regarding the maximum number of people per group. } \\
\text { Wear a mask (Compulsory) } \\
\text { Ensure compliance with social distancing rules: before, during after a tour. } \\
\text { Respect minimum distance between clients during visits, breaks and stops. } \\
\text { For guides in natural areas, used equipment must be systematically disinfected } \\
\text { after each use. } \\
\text { Have emergency numbers. } \\
\text { Take a hygiene kit (masks, gloves, disinfectants, etc.). } \\
\text { Use audio equipment for visits. } \\
\text { Check if customers wear masks (to be renewed every } 4 \text { hours). } \\
\text { Stop any tour if the guide or a customer have symptoms of COVID } 19 . \\
\text { Use electronic payment. }\end{array}$ \\
\hline
\end{tabular}

Thus, the collection of recommendations published on June 1, 2021, presents the list of protective measures against COVID 19 that must be put in place: before, during and after every service. The collection was intended mainly for accommodation establishments, restaurants, travel agencies and guides. No mention is made for of transportation. It will be included in other recommendations made by the ministry of interior. 
Indeed, after the injunctions for a complete closure of coffee shops, restaurants, Hammams, swimming pools and the ban on all cultural and groups events as well as all travel, during the lockdown. The lifting of these restrictions was done in three different phases and zones. 50\% gauges, openings from 8 a.m. until 11 p.m. and curfews have been established. With the curfew still in place, several establishments were not authorized to open, depending on the zone where they are: Hammams, Spa, swimming pools... and events were banned, then banned with a maximum capacity of 50 people. The carriers for their part had to comply with the gauge of $50 \%$ during the first stage and $75 \%$ before going back to $50 \%$ of the capacity with the respect of the fundamental obligations: physical distance, mask and regular disinfection. The deterioration of the health situation is behind the permanent change in the given recommendations.

At the environmental level, if a relaxation was felt during the first months of the pandemic. The recommendations and action of the Ministry of the Environment aimed at accentuating controls in fragile and protected areas and raising awareness of the repercussions of the pandemic on ecosystems. The management of new wastes linked to health care or prevention (tests, masks) was the subject of an awareness campaign of the Ministry of the Environment [75].

In short, the governance of the crisis was carried out under the sign of the state of emergency [76]. This situation framed by the Decree-Law No. 2-20-292 of March 23, 2020 [76]. In such situations, the authorities have full prerogatives to take all necessary preventive, urgent and immediate measures, decisions, laws and recommendations to fight the pandemic. The consultation of the ecotourism and tourism actors was thus very limited, but the involvement of all the stakeholders was vaguely requested. It has certainly made it possible to control the spread of the virus, despite the big economic and social losses. It has also initiated the first new transformations that ecotourism will undergo in the coming years.

\section{Results}

The field study was conducted on a sample of 30 ecotourism professionals. In choosing sample elements we favored a strong presence of the private actors $(96.66 \%)$, since it is the most affected by the pandemic. SME offering accommodation services are the most important $(66.66 \%)$ part followed by transportation companies and cooperatives. Each of these last companies represents $13.33 \%$ of the sample (table.3).

Table. 3. Field study sample composition

\begin{tabular}{|l|c|c|c|c|c|c|}
\hline \multirow{2}{*}{ Actors } & \multicolumn{2}{|c|}{ Sample } & \multicolumn{2}{c|}{ Men } & \multicolumn{2}{c|}{ Women } \\
\cline { 2 - 7 } & $\mathbf{N}$ & $\mathbf{\%}$ & $\mathbf{N}$ & $\mathbf{\%}$ & $\mathbf{N}$ & \% \\
\hline Guide & 1 & $3,34 \%$ & 1 & $3.34 \%$ & - & - \\
\hline Homestay & 3 & $10 \%$ & 3 & $10 \%$ & - & - \\
\hline Guest houses & 11 & $36,66 \%$ & 8 & $26,66 \%$ & 3 & $10 \%$ \\
\hline Lodges & 6 & $20 \%$ & 6 & $20 \%$ & - & - \\
\hline Cooperatives & 4 & $13,34 \%$ & 1 & $3,33 \%$ & 3 & $10 \%$ \\
\hline Provincial tourism Office & 1 & $3,33 \%$ & 1 & $3,33 \%$ & - & - \\
\hline Transportation & 4 & $13,33 \%$ & 4 & $13,33 \%$ & - & - \\
\hline Total & $\mathbf{3 0}$ & $\mathbf{1 0 0} \%$ & $\mathbf{2 4}$ & $\mathbf{8 0 \%}$ & $\mathbf{6}$ & $\mathbf{2 0 \%}$ \\
\hline
\end{tabular}

The typology of the hosts is made of guest houses, lodges and homestay providers. A situation that we can justify by the absence of other types of structures working in the area. Indeed, Essaouira has only one official guide of natural spaces. Likewise, the agencies that offer activities in the hinterland of Essaouira are based in other cities. Providers of activities 
such as horse riding, surfing, windsurfing... exist, but their activity is more recreational. In addition, the territory does not offer entry rights to the reserve and does not have an Eco museum outside the city. This is what justifies our choice of Argan and goat cheese cooperatives, which remains the only establishments that offer free tours in a formula that is somewhat similar to agro tourism. The propensity of men is higher $(80 \%)$ compared to women (only $20 \%$ ). The latter is either managers of guest houses $(10 \%)$ or cooperatives $(10 \%)$. The sector is strongly dominated by men, at least for owners and managers. Only cooperatives have a strong presence of women.

Generally speaking, all the questioned people are unanimous in confirming the negative impact of covid19 pandemic on ecotourism locally (table.4). All the hosts confirmed that they have being obliged to cancel their booking, from mid-march 2020 to the study date. Only two guest houses are preparing their re-opening for 2021 summer season, and the rest has remained closed. The only guide working in the area had lost his business and the same for transporters. This situation was confirmed by the tourism office delegate as suggested above in the official statistics about the impact of covid19.

Table.4. Themes and most listed elements during the interviews

\begin{tabular}{|c|c|}
\hline Themes & Most listed elements \\
\hline $\begin{array}{l}\text { Negative } \\
\text { impacts }\end{array}$ & $\begin{array}{l}\text { Bookings cancellation } \\
\text { Stoppage of the whole activity } \\
\text { Deposits and fully paid bookings reimbursements } \\
\text { Declaration of financial difficulty and inability to repay bank loans } \\
\text { inability to meet fixed charges due to prolonged emergency measures; } \\
\text { Treasurer exhausted by reimbursements and salaries } \\
\text { Employees dismissal and lack of staff } \\
\text { No clear strategy due to emergency status and borders closers; } \\
\text { Difficulty to plan marketing activities; temporary stoppage of promotion, } \\
\text { marketing and attendance at fairs and events. } \\
\text { New expenses related to sanitary measures and products and to the training of } \\
\text { teams to the new processes }\end{array}$ \\
\hline $\begin{array}{l}\text { Engaged } \\
\text { actions }\end{array}$ & $\begin{array}{l}\text { Closure and cessation of activity } \\
\text { lower wages } \\
\text { Declaration of the cessation of activity } \\
\text { Request for CNSS (Caisse Nationale de Sécurité Sociale) aids } \\
\text { Awaiting opening decisions } \\
\text { Loan request } \\
\text { Maintaining links with customers through the phone and social networks } \\
\text { Search and diversify clients by seeking new markets (local) } \\
\text { Implement new health protocols and prepare for the opening (by following the } \\
\text { new measures for welcoming clients) } \\
\text { Reorganize the staff activities in respect of the new measures } \\
\text { Develop new products or experiences }\end{array}$ \\
\hline $\begin{array}{l}\text { Measures } \\
\text { requested } \\
\text { within the } \\
\text { framework of } \\
\text { State actions }\end{array}$ & $\begin{array}{l}\text { Declaration of the cessation of activities } \\
\text { Suspension of payment of social charges (CNSS contributions) } \\
\text { request for monthly lump sum compensation for employees; } \\
\text { Request for postponement of loan maturities without payment of fees or late } \\
\text { penalties } \\
\text { Request for postponement of tax declarations and deadlines (corporate tax, } \\
\text { declaration of taxable incomes) }\end{array}$ \\
\hline $\begin{array}{l}\text { Potential } \\
\text { changes in } \\
\text { ecotourism }\end{array}$ & $\begin{array}{l}\text { A slow return to normal; } \\
\text { A demand mindful of the pandemic risk and services; } \\
\text { The vaccination obligation } \\
\text { The obligation of a health passport; } \\
\text { Adaptation of services including health measures; }\end{array}$ \\
\hline
\end{tabular}


Because of the lockdown, accommodations were thus forced to stop their activity. A situation that has been prolonged because of the continued extension of the state of health emergency. Consequently, a series of negative impacts followed. Most significant impacts have a financial component. The majority of managers questioned evoke that they had to reimburse deposits and payments received, that they declared their financial difficulty and have been unable to pay bank loans. The extension of the emergency measures has also led to the incapacity to ensure even the fixed costs for $90 \%$ of the companies. Some of them were forced to dismiss employees (70\%) because of a cash flow burdened by three months of lockdown and a long inactivity charges. The nature of companies, especially composed of SME's, means that they have not been able to plan to reopen after the lockdown lifting nor to be able to prepare an effective marketing strategy, preferring to continue their closure, despite the encouragement of the State to reopen for domestic tourists. Two guest houses which are preparing for the future opening are doubtful as to the strategy to be adopted in terms of price while new charges must be borne, mainly due to sanitary measures and protocols: purchase of masks and sanitizers, permanent disinfection of premises and staff training to new health and service procedures.

In sum, the situation remains complicated for all the questioned operators. First of all because of the state of health emergency and closure of borders for international customers and because of the obligation of travel authorizations and incessantly prolonged curfews for the local market. It is also these reasons which pushed the owners of accommodation, transport and cooperatives to go through emergency actions such as stopping their activity $(100 \%)$, lower wages $(95 \%)$ then the declaration of cessation of activity $(100 \%)$. All of them have also appealed to the aids for employees and requested for the postponement of credit maturities. Other actions such as searching for new markets, maintaining contact with customers and suppliers as well as reorganizing the work process and developing new products and experiences are also cited by some of them. This is the case of cooperatives that have tried to sell their products through new channels (online) while they were previously dependent on tourism activity. Even while waiting for the lifting of emergency measures, all of the interviewed declared that they took the pandemic risks seriously and made an effort to implement new health protocols. We were able to observe these measures in cooperatives and the tourist office which remained open after the lockdown. The other companies preferred to stay closed.

In any event, all of the respondents appear satisfied with the management and governance of the current crisis. Especially during the beginning of the pandemic. For the sample questioned, the health situation remains a priority and justifies decisions like lockdown and stopping the activity. Ditto for the aid measures which have made it possible to reduce the shock of the period of complete cessation of activity. However, the opinions of operators appear to differ when it comes to last minute decisions to limit travels and curfews. $65 \%$ believe that the situation requires that kind of decisions while the rest think that operators should be given more time to be able to open without incurring stealthy and last-minute decisions.

When it comes to ecotourism return to normal and the changes that will affect the sector, the interviewees are pessimistic. For all of them, the return to normal will take a long time because of the pandemic constraint and the accompanying measures (state of emergency, border closures, curfews, compulsory quarantine, etc.).These decisions will certainly affect the tourists' motivations. They are and will remain increasingly concerned with the travel health risks and constraints. For all the operators, this situation will seriously mark ecotourism in the short and medium terms. Thus, the vaccination obligation and the health passport will be decisive elements in tourist admission in countries borders.

In the same vein, ecotourism will be marked by profound changes in terms of supply. According to all interviewees, generalized and mandatory health protocols will be an 
integral part of the services they offer. They will be certainly decisive in travel decisions and destinations choices.

\section{Conclusion}

Ecotourism has been deeply affected by the covid19 pandemic. The catastrophe magnitude is huge, and the states and operators are still under the shock. They all proceed by trial and error to find a solution to the spread of the pandemic and its economic and social impact. There is still a long way to go despite the progress in terms of vaccinations and the efforts made to minimize the economic shock.

This study sheds light on the issues linked to covid19 and the changes in ecotourism in Morocco and more particularly in the province of Essaouira. It is a contextual study conducted during the period of covid19. Through an analysis of the measures which accompanied the attempts to revive the activity and a field study, it reveals the important the impact of the pandemic on Moroccan ecotourism and the difficulties of companies to rethink the post-covid period. It also gave an overview of the profound transformations that the sector will undergo in light of the measures imposed by the Moroccan authorities.

More than ever before, the sector appears to be heavily impacted. The domino effect on the various operators and providers is unequivocal. The closure of establishments, the layoffs, the declaration of financial difficulty have plunged ecotourism operators into a hellish loop of difficulties and deficits. The state's efforts to alleviate the impact of the crisis, although appreciable, do not allow an easy return to normal. All companies are struggling to design their start-up because of the uncertainty associated with the pandemic and the inconsistent recommendations of decision-makers.

In this frame, Covid19 shock is a rupture moment. It foreshadows profound changes in the whole ecotourism system. From now on, health considerations will be an integral part of the service offer of the various providers. Reconstructing the ecotourism supply will involve a strong health component in the service delivery process. Airlines, ground transportation, accommodation providers, museums, guides or restaurateurs all must review their services processes and arguments to be able to reassure their clientele in the future.

\section{References}

1. S. Sareen, K. B. Nielsen, P. Oskarsson, D. Remme. Front. Hum. Dyn 3:636422. (2021)

2. N. G. Uğur., A. Akbıyı. Tour. Manag. Perspect, 36, 100744. (2020)

3. M. Sigala. J. Bus. Res, 117. 312-321. , (2020)

4. N. A. Bakar, \& S. Rosbi. Int. j. adv. eng. res. sci., 7(4), 189-193. (2020)

5. JW. Morse, TM. Gladkikh, DM. Hackenburg, RK. Gould. PLoS One. 15(12). (2020)

6. J.A. McNeely. Ambio 50, 767-781 (2021).

7. P. Girish. Time for rest? TRI, Volume 24, N²-3, (2020). 179-184(6).

8. AEFCS. Plan Directeur des Aires Protégées du Maroc. Administration des Eaux et Forêts et de la Conservation des Sols/BCEOM/SECA/ISR/EPHE. (non published report). (1996)

9. M. Dakki, M. A El Agbani, \& Qninba, Trav Instit Scienti, Rabat, 7: 238 pp. (2011)

10. C. Magin. Morocco. Bird Inter. Ser. 11. (2001)

11. A. Benabid. Flore et écosystéme du Maroc, (Ibis Press. 2000).

12. A. Jurowski, U. Muzaffer, and W. Daniel. 35 (Fall): 3-11. (1997)

13. J. Liu, \& V. Turgut (1986). Ann. Tour. Res, 13: 193-214. (1986)

14. J. R. Ritchie. JTR, 38 (2): 100-10. (1999)

15. R. Schweitz. J for Qual and Parti, September: 36-40. (1996) 
16. R. E. Owen, S. Witt., S. Gammon. T.M, December: 463-74. (1993)

17. J. R. MacGregor. Sustainable Tourism Development." In VNR's Encyof Hosp and Tou, in M. Khan, M. Olsen, and T. Var. New York (Eds): Van Nostrand Reinhold (1993).

18. V. Vincent, W. Thompson. JTR, Vol. 41, November. 153-160 Sage Publi (2002).

19. A. Girard. B. Schéou. M en Dévelo, 157(3), 67- 80. (2012)

20. R. Sadki, M. El Wartiti, R. Azelmad, and S. Berred, IJIAS vol. 18-3. 784-793, November (2016)

21. M. Berriane. Z.F.T. 12(2), 158-183, (2020)

22. Y. El Azyzy. CirVath Inter Jour of T, 10(3), 123-142. (2018)

23. H. Zaoul, Rev Org et march, 3.155-182. : (2007).

24. H. Faouzi. \& W. Affaghrou, RIMEC, $04 \mid(2020)$,

25. Ouassini, N. Ouassini. JAAS. July. (2020).

26. M. Hall, Ecotourism and biosecurity, in Higham. J., (Ed). Critical issues in ecotourism, understanding a complex tourism phenomenon. Butterworth-Heinemann, Elsevier. 121135. (2007)

27. C.M. Hall, D. Scott, D. Gössling. Tour. Geogr 22:3, (2020).

28. C.M. Hall, M. James. Tour. Rev 66(1/2): 118-126. (2011)

29. C.M. Hall, Biological invasion, biosecurity, tourism, and globalization. In Handbook of Globalization and Tourism. 114-125. (2019).

30. J. Hanrahan, D. Melly. EJTR 22. 45-61.(2019)

31. B. Zeng, R. W. Carter., Curr. Issues Tour. 8(4). 306-322. (2005).

32. S. Sönmez, J. Wiitala, Y. Apostolopoulos, How complex travel, tourism, and transportation networks influence infectious disease movement in a borderless world. In: J.T. Dallen, (ed.) Handbook of Globalization and Tourism. (Cheltenham: Edward Elgar Publishing, 76-88. (2019)

33. B. Zeng, R. W. Carter., T. De Lacy. Curr. Issues Tour 8(4). 306-322. (2005)

34. H. Joo, B.A. Maskery, A.D. Berro, et al. Health Secur. 17(2). 100-108. (2019)

35. K.K. Hung, C.K. Mark, M.P. Yeung, et al. Glob. Health 14(1) (2018)

36. P. M. Maphanga, U. S. Henama. Afr. J. Hosp. Tour. Leis 8(3).59. (2019)/

37. S. Sareen, K. B. Nielsen, P. Oskarsson, D. Remme. Front. Hum. Dyn 3:636422. (2021)

38. S. Thomson, and Ip, E. C. J. Law Biosci.7 (1), Isaa064. (2020)

39. M. K. Haywood. Tour. Geogr, 22:3, 599-609, (2020)

40. G. D. Sharma, A. Thomas, J. Paul. Tour. Manag. Perspect, 37. 100786. (2021)

41. M. Traskevich, A. Fontanari, Tour. Plan. Dev. 03-03. (2021)

42. S. Benjamin, A. Dillette, D.H. Alderman. Tour. Geogr. (2020)

43. M. F. Orïndaru, A.P. Popescu, S.C. Alexoaei, M.S. Ca escu, A.O. Florescu, Sustainability 13, 6781(2021).

44. H. C. Goh, Glob.Res, 3, December (2021).

45. P. Wight. Jour. Tour. Stud. 4(2):54-66. (1993)

46. J. C. Isaacs. Wildl. Soc. Bull. 28:61-69. (2000)

47. S. Cherkaoui, M Boukherouk, T. Lakhal, A. Aghzar, L. El Youssfi. Conservation Amid COVID-19 Pandemic: Ecotourism Collapse Threatens Communities and Wildlife in Morocco. InProceedingof the 2020 International Conference on Climate Nexus Perspectives: Water, Food and Biodiversity, I2CNP, Scopus. 183, 2020.

48. M. Honey, (1999). Ecotourism and Sustainable Development: Who Owns Paradise?: (Island Press. 1999)

49. J. K. Sharma. Tourism and Development-Design for Ecological Sustainability. (Kanishika Publishers \& Distributors. 2000)

50. The International Ecotourism Society, General Tourism Statistics (2000),

51. V. Himanshu, R. Deshmukh, AMR (2021)

52. CREST. The Case for Responsible Travel: Trends \& Statistics. (2018) 
53. Booking https://news.booking.com/fr/ecotourisme--76-des-francais-souhaitent-que-dessolutions-durables-soient-mises-en-place-rapidement-selon-une-etudebookingcom/(2019)

54. Booking. $\quad$ https://news.booking.com/87--des-voyageurs-internationaux-declarentsouhaiter-voyager-en-limitant-leur-impact-sur-lenvironnement-selon-une-etudebookingcom/ (2018)

55. B. Moudoud, Thesis (Doctoral), Université Joseph Fourier-Grenoble I. 2000

56. A. Billand. Rev. Géogr. Alp. 84-4. Pp 95-108. (1996)

57. OMT-PNUD, Stratégie de développement du tourisme rural, (2002).

58. DPT. Monographie touristique de la province d'Essaouira, internal document. (2021)

59. La clef verte website. (2021)

60. WTO, L'impact de la COVID-19 sur le tourisme mondial apparaît dans toute son ampleur alors que l'OMT chiffre le coût du blocage, 28 juin 2020, in https://www.unwto.org/fr/news/limpact-de-la-covid-19-sur-le-tourisme-mondialapparait-dans-toute-son-ampleur-alors-que-lomt-chiffre-le-cout-du-blocage

61. WTO, 2020 aura été la pire année de l'histoire du tourisme avec 1 milliard d'arrivées internationales en moins, 21 janvier 2021, in https://www.unwto.org/fr/news/2020-auraete-la-pire-annee-de-1-histoire-du-tourisme-avec-1-milliard-d-arrivees-internationalesen-moins

62. B. Berrissoule. L'Economiste, 5721. 18/03. (2020)

63. General Secretariat of the Government. B.O. 6240. 20 mars. (2014).

64. General Secretariat of the Government. BO. 5118. 507. 19.06 (2003)

65. General Secretariat of the Government, B.O. 177. 13 mars. (1916).

66. General Secretariat of the Government, B.O. 1780. 06-12-(1946)

67. Ministère de la santé, Programme de la surveillance épidémiologique, report, 2010

68. Ministère de la santé, Plan national de veille et de riposte à l'infection par le coronavirus 2019-nCov, Version Janvier 202

69. A. Ait Ali, A. Bassou, M. Dryef, K. EL Ayanoui, R. El Houdaigui, Y. El Jai, F. Hossaini, L. Jaidi, M. Loulichki, E.Rezrazi, A. Saaf, PCNS. Avril 20-07. (2020).

70. XZ DCAF \& CEDHD, Gestion de l'état d'urgence sanitaire au Maroc, gouvernance sécuritaire et droit humains, Report, juillet (2020)

71. CRI, Résumé des mesures du comité national de veille économique, Région de Casablanca-Settat, in CRI Website (2019).

72. DRDQ, Website. Recueil de recommandations de sécurité sanitaire liées au Covid19 à destination des opérateurs touristiques marocains, Ministère du Tourisme, de l'Artisanat, du Transport Aérien et de l'Economie Sociale Département du Tourisme. (2020)

73. H. Dari. Challenge Online. (2020).

74. CESE (Conseil Economique Social et environnemental), (2020), Saisine 28. (2020).

75. Département de l'environnement, (2020), Press release (2020)

76. General Secretariat of the Government, Morocco. B-O. 6870. 506-85. (2020) 